\title{
Gambaran Kualitas Hidup Pasien Miastenia Gravis Di RSUP Dr. M. Djamil Padang
}

\author{
Fadel Muhammad ${ }^{1}$, Yuliarni Syafrita ${ }^{2}$, Lydia Susanti ${ }^{2}$
}

\begin{abstract}
Abstrak
Miastenia Gravis (MG) merupakan kelainan autoimun yang menyerang reseptor neurotransmitter di tautan neuromuskular dan menghambat terjadinya kontraksi otot. Kelemahan otot yang terjadi menyebabkan keterbatasan aktivitas fisik serta mempengaruhi setiap aspek dari kualitas hidup. Tujuan penelitian ini adalah untuk mengetahui gambaran kualitas hidup pada pasien miastenia gravis di RSUP Dr. M. Djamil Padang. Penelitian ini merupakan studi deskriptif dengan desain cross sectional melibatkan 38 pasien yang telah menyetujui informed consent dan berusia 20-79 tahun. Pengambilan sampel menggunakan teknik consecutive sampling. Instrumen yang digunakan adalah kuesioner WHOQOL-BREF. Kualitas hidup baik jika didapatkan skor akhir 51-100 dan kualitas hidup kurang jika didapatkan skor akhir 0-50. Analisis data menggunakan analisis univariat. Pengumpulan data dilakukan pada data rekam medis. Hasil penelitian menunjukkan responden paling banyak berusia 20-49 tahun (76,3\%), berjenis kelamin perempuan $(84,2 \%)$, MGFA kelas II $(63,2 \%)$, dan lama menderita rata-rata 56,87 bulan dengan median 45 bulan. Kualitas hidup $89,5 \%$ baik, rata-rata skor 63,7 . Kesimpulan penelitian ini adalah secara umum kualitas hidup pasien $M G$ adalah baik, terdapat kecenderungan penurunan skor akhir kualitas hidup seiring dengan lamanya mederita dan meningkatnya kelas MGFA.
\end{abstract}

Kata kuncl: kualitas hidup, MG, WHOQOL-BREF

\section{Abstract}

Myasthenia gravis (MG) is an autoimmune disorder that attacks neurotransmitters receptor in neuromuscular junction and inhibits muscle contraction. Muscle weakness causes the limitations of physical activity and affect every aspect of quality of life. The objective of this study was to determine the quality of life in myasthenia gravis patients in Dr. M. Djamil Hospital Padang City. This study is a descriptive with cross-sectional design involving thirtyeight patients who have approved informed consent and aged between twenty to seventyfive years old. Sampling using consecutive sampling technique. The instrument used is the WHOQOL-BREF questionnaire. Quality of life is good if the final score is 51-100, and quality of life is lacking if the final score is 0-50. Data analysis using Univariate analysis. Data collection is done by medical record data.The results of the study showed that respondents were aged twenty to fourty nine years old (76.3\%), female (84.2\%), MGFA class II (63.2\%), and suffered with mean 56.87 months median fourty five months. Quality of life is $89.5 \%$ good, mean score is 63.7 . The conclusion of this study is that the quality of life of $M G$ patients is good, there is a downward trend of the final score of quality of life according to the duration of sickness and stepping-up of MGFA class.

Keywords: quality of life, MG, WHOQOL-BREF

Affiliasi penulis: 1. Prodi Kedokteran Fakultas Kedokteran

Universitas Andalas Padang (FK Unand), 2. Bagian Neurologi FK Unand/RSUP Dr. M. Djamil Padang.

Korespondensi :Fadel Muhammad,

email:emailfadelmuhammad@gmail.com Telp: 082287519718

\section{PENDAHULUAN}

Miastenia gravis (MG) adalah suatu bentuk kelainan pada transmisi neuromuskular / disorders of neuromuscular transmission (DNMT) yang paling sering terjadi.Pada MG terjadi permasalahan transmisi yang mana terjadi pemblokiran reseptor asetilkolin 
(AChR) di serat otot (post synaptic) mengakibatkan tidak sampainya impuls dari serat saraf ke serat otot (tidak terjadi kontraksi otot). Miastenia gravis ditandai oleh kelemahan otot yang kembali memulih setelah istirahat. Miastenia dalam bahasa latin artinya kelemahan otot dan gravis artinya parah. ${ }^{1}$ Departemen kesehatan Amerika Serikat mencatat jumlah pasien MG diestimasikan sebanyak 5 sampai 14 dari 100.000 orang populasi pada seluruh etnis maupun jenis kelamin. ${ }^{2}$ Di Indonesia sendiri belum ditemukan data yang akurat terkait angka kejadian MG. Populasi MG terbilang kecil apabila dibandingkan dengan jumlah seluruh penduduk di Indonesia. Meskipun jumlahnya yang sedikit namun pasien tetap merasakan berbagai dampak fisik maupun psikososial yang ditimbulkan oleh proses penyakit. ${ }^{3}$ Studi pendahuluan yang dilakukan pada bulan Oktober - November 2017 di Poliklinik Saraf Rumah Sakit Umum Pusat (RSUP) Dr. M. Djamil Padang, didapatkan 62 pasien MGdari periode Mei 2015 - Mei 2017.

Menurut Myasthenia Gravis Foundation of America (MGFA), miastenia gravis diklasifikasikan menjadi 4 kelas. Kelas I, adanya kelemahan otot-otot okular, kelemahan pada saat menutup mata, dan kekuatan otot-otot lain normal. Kelas II, adanya kelemahan ringan pada otot-otot lain selain otot okular, otot okular mengalami kelehaman dalam berbagai derajat. Kelas III, adanya kelemahan tingkat sedang pada otot-otot lain selain otot okular, otot okular mengalami kelemahan dalam berbagai derajat. Kelas IV, adanya kelemahan dalam derajat yang berat pada otot-otot selain otot okular, sedangkan otot-otot okular mengalami kelemahan dalam berbagai derajat. Kelas $\mathrm{V}$, pada kelas ini penderita terintubasi, dengan atau tanpa ventilasi mekanik. ${ }^{4}$

Salah satu permasalahan yang dialami oleh pasien MG adalah memiliki kondisi bekerja yang kurang ideal. Kondisi ini terjadi terutama karena gangguan fisik sehingga menyebabkan tujuan pekerjaan tidak dapat tercapai. Beberapa pasien MG mengalami kesulitan dalam aktivitas sekolah atau bekerja serta masalah dalam menghadapi kehidupan sehari-hari mereka. ${ }^{5}$ Miastenia gravis memiliki konsekuensi psikologis seperti gangguan kecemasan, meliputi gangguan panik serta gangguan depresif. ${ }^{6}$ Selain itu, perubahan karakteristik pada pasien MG menyebabkan pasien menjadi cepat marah, tegang dan merasa khawatir. ${ }^{6}$

Penelitian tentang kualitas hidup miastenia gravis yang menggunakan kuesioner Medical Outcome 36 Item Short Form Health Survey (SF-36) yang melibatkan 188 pasien dengan MG di Tiongkok didapatkan 95 orang berjenis kelamin laki-laki, 93 orang perempuan, 104 orang dengan miastenia gravis okuler, 84 orang dengan miastenia gravis generalisata. Skor paling tinggi atau kualitas hidup baik terdapat pada komponen bodily pain atau nyeri, skor terendah atau kualitas hidup kurang didapatkan pada komponen role functioning physical atau peran fisik. Tidak ada perbedaan yang signifikan antara kualitas hidup jenis

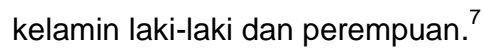

Penelitian tentang kualitas hidup miastenia gravis menggunakan kuesioner Myasthenia Gravis Qualitiy of Life-15 (MG-QoL-15) yang melibatkan 50 pasien MG di India didapatkan tidak ada perbedaan signifikan antara jenis kelamin, usia, timoma, status timektomi terhadap kualitas hidup, tetapi ditemukan perbedaan skor yang signifikan terhadap kelas atau derajat MG berdasarkan MGFA. Skor yang baik didapatkan pada MGFA kelas I dan II, sementara skor paling rendah didapatkan pada MGFA kelas III dan IV. $^{8}$

Rehabiliterings Center For Muskelsvind dalam penelitannya tentang Characteristics of Long-time Patients with Myasthenia Gravis in a Danish Population, saat penelitian dilakukan, ditemukan 39 orang menderita MG selama 24-76 bulan, 35 orang menderita MG selama 77-128 bulan, dan 19 orang menderita MG selama 128-180 bulan. Kualitas hidup diukur dengan menggunakan kuesinoer WHOQOLBREF dan didapatkanpenurunan skor pada setiap dimensi / domain kualitas hidup, seiring dengan lamanya menderita $\mathrm{MG}^{9}{ }^{9}$

World Health Organization (WHO) menjelaskan bahwa sehat tidak hanya terbebas dari penyakit dan kelemahan, tetapi juga terdapatnya kesejahteraan fisik, mental dan sosial. Hal-hal tersebut merupakan hal-hal yang menjadi masalah pada pasien MG karena pada pasien tersebut terjadi penurunan kualitas hidup yang meliputi aspek-aspek tersebut. ${ }^{10}$

World Health Organization Quality of Life (WHOQOL) mengemukakan kualitas hidup adalah 
persepsi seseorang dalam konteks budaya dan norma yang sesuai dengan tempat hidup orang tersebut serta berkaitan dengan tujuan, harapan, standar dan kepedulian selama hidupnya. Kualitas hidup seseorang merupakan hal yang multi dimensional. Hal ini merupakan suatu konsep yang dipadukan dengan berbagai cara seseorang untuk mendapat kesehatan fisik, keadaan psikologis, tingkat independen, hubungan sosial dan hubungan dengan lingkungan sekitarnya. $^{11}$

Sejak 1991, WHO telah mengembangkan instrumen untuk mengukur kualitas hidup. Instrumen tersebut kemudian diberi nama World Health Organization Quality of Life Scale (WHOQOL-BREF), merupakan alat ukur yang valid $(r=0,89-0,95)$ dan reliable ( $R=0,66-0,87$ ). Instrumen ini terdiri dari 26 item pertanyaan yang terdiri dari empat domain/ dimensi, yaitu; Dimensi kesehatan fisik, dimensi psikologis, dimensi hubungan sosial dan dimensi lingkungan. $^{12}$

Sebagai pemberi layanan atau care provider kepada pasien maka dokter dan tenaga kesehatan lainnya dapat berperan dalam memberikan edukasi tentang penyakit, prognosis serta perawatannya, sehingga pasien MG dapat meningkatkan kualitas hidupnya. Berdasarkan uraian tersebut peneliti tertarik untuk melakukan penelitian tentang gambaran kualitas hidup pasien MG di RSUP Dr. M. Djamil Padang.

\section{METODE}

Penelitian ini adalah penelitian deskriptif dengan desain cross-sectional untuk mengetahui kualitas hidup pasien miastenia gravis di Rumah Sakit Umum Pusat (RSUP) Dr. M. Djamil Padang.

Penelitian ini dilakukan di Bagian Saraf RSUP Dr. M. Djamil Padang terhadap pasien yang telah memenuhi kriteria penelitian yang telah ditetapkan oleh peneliti. Alasan dilakukan penelitian ini dikarenakan belum pernah dilakukan penelitian serupa mengenai kualitas hidup pasien MGdi RSUP Dr. M. Djamil Padang.

Populasi dari penelitian ini adalah seluruh pasien MG di RSUP Dr. M. Djamil Padang yang mana pada bulan Mei 2015 - Mei 2017 di Poliklinik Saraf berjumlah 62 orang. Sampel pada penelitin ini adalah pasien miastenia gravis yang telah memenuhi kriteria inklusi yang telah ditetapkan.Kriteria inklusi subjek: pasien dengan diagnosis MG yang sedang menjalani terapi, berusia 20-79 tahun, mampu berkomunikasi secara verbal dan baik, pasien yang kooperatif, menyetujui informed consent dan bersedia menjadi partisipan selama penelitian berlangsung.Kriteria eksklusi subjek: pasien dengan krisis miastenik.

Data diperoleh dengan cara wawancara menggunakan kuesioner dan catatan rekam medis. Kuesioner yang digunakan adalah WHOQOL-BREF untuk menentukan kualitas hidup.

Analisis univariat dilakukan terhadap tiap varibel dari hasil penelitian ini untuk melihat distribusi dan persentase yang meliputi usia, jenis kelamin, derajat miastenia gravis dan lama menderita miastenia gravis.

\section{HASIL}

Penelitian ini dilakukan pada bulan Desember 2017 sampai Februari 2018, dengan jumlah responden sebanyak 38 orang yang memenuhi kriteria inklusi.

\section{Karakteristik Responden}

Tabel 1. Distribusi frekuensi karakteristik pasien miastenia gravis (MG) di RSUP Dr. M. Djamil Padang

\begin{tabular}{|c|c|c|c|c|}
\hline No & Karakter & Responden & $f$ & $\%$ \\
\hline \multirow{2}{*}{1} & \multirow{2}{*}{ Usia } & 20-49 tahun & 29 & 76,3 \\
\hline & & 59-79 tahun & 9 & 23,7 \\
\hline \multirow{2}{*}{2} & Jenis & Laki-laki & 6 & 16,8 \\
\hline & Kelamin & Perempuan & 32 & 84,2 \\
\hline \multirow{4}{*}{3} & \multirow{4}{*}{ Kelas MG } & I & 7 & 18,4 \\
\hline & & II & 24 & 63,2 \\
\hline & & III & 7 & 18,4 \\
\hline & & IV & 0 & 0 \\
\hline \multirow{2}{*}{4} & Lama & $<45$ bulan & 19 & 50 \\
\hline & Menderita & $>45$ bulan & 19 & 50 \\
\hline Total & & & 38 & 100 \\
\hline
\end{tabular}

Berdasarkan Tabel 1 dapat dilihat bahwa pasien MG di RSUP Dr. M. Djamil Padang terbanyak berusia 20-49 tahun yaitu sebanyak 29 orang (76,3\%), diikuti usia 59-79 tahun sebanyak 9 orang (23,7\%). Jenis kelamin terbanyak adalah perempuan sebanyak 32 orang $(84,2 \%)$, diikuti dengan laki-laki sebanyak 6 orang $(16,8 \%)$. Kelas miastenia gravis berdasarkan MGFA terbanyak adalah kelas II sebanyak 24 orang 
(63,2\%), diikuti kelas I dan kelas III masing-masing nya sebanyak 7 orang (18,4\%), sementara kelas IV tidak ditemukan. Lama menderita miastenia gravis < <5 bulan dan $>45$ bulan masing-masingnya sebanyak 19 orang (50\%).

\section{Gambaran Kualitas Hidup Pasien MG}

Gambar 1 memperlihatkan bahwa dari 38 pasien miastenia gravis di RSUP Dr. M. Djamil Padang, 89,5\%(34 orang) memiliki kualitas hidup baik dan 10,5\%(4 orang) memiliki kualitas hidup kurang.

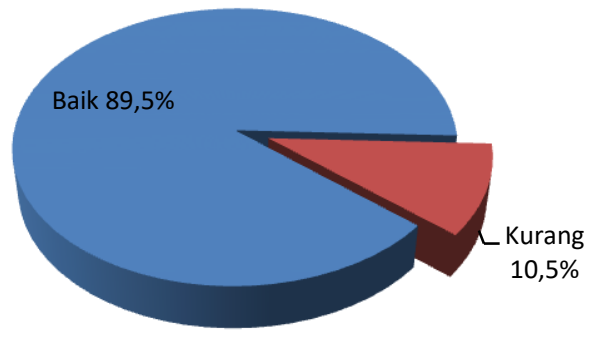

Gambar 1. Diagram gambaran kualitas hidup pasien MG di RSUP Dr. M. Djamil Padang.

Gambaran Kualitas Hidup Pasien MG Berdasarkan Karakteristik Responden

Tabel 2. Distribusi frekuensi kualitas hidup pasien MG di RSUP Dr. M. Djamil

\begin{tabular}{clcccc}
\hline \multirow{2}{*}{$\begin{array}{c}\text { Karakteristik } \\
\text { Responden }\end{array}$} & \multicolumn{3}{c}{ Bualik } & \multicolumn{2}{c}{ Kurang } \\
& & f & $\%$ & f & $\%$ \\
\hline \multirow{2}{*}{ Usia } & 20-49 tahun & 25 & 86,2 & 4 & 13,8 \\
& 59-79 tahun & 9 & 100 & 0 & 0 \\
Jenis & Laki-laki & 5 & 83,3 & 1 & 16,7 \\
Kelamin & Perempuan & 29 & 90,6 & 3 & 9,4 \\
& I & 7 & 100 & 0 & 0 \\
Kelas MG & II & 21 & 87,5 & 3 & 12,5 \\
& III & 6 & 85,7 & 1 & 14,3 \\
& IV & 0 & 0 & 0 & 0 \\
Lama & $<45$ bulan & 17 & 89,5 & 2 & 10,5 \\
Menderita & $>45$ bulan & 17 & 89,5 & 2 & 10,5 \\
Total & & $\mathbf{3 4}$ & $\mathbf{8 9 , 5}$ & $\mathbf{4}$ & $\mathbf{1 0 , 5}$ \\
\hline
\end{tabular}

Tabel 2 memperlihatkan bahwa kualitas hidup pasien MG di RSUP Dr. M. Djamil Padang pada usia 20-49 tahun 86,2\% adalah baik dan pada usia 50-79 tahun $100 \%$ baik. Tidak ada hubungan antara pasien MG kelompok usia 20-49 tahun dengan kelompok usia 50-79 tahun terhadap kualitas hidup $(p>0,05)$

Kualitas hidup pasien MG di RSUP Dr. M. Djamil Padang berjenis kelamin laki-laki 83,3\% baik, perempuan $90,6 \%$ baik. Tidak ada hubungan antara jenis kelamin pasien miastenia gravis terhadap kualitas hidup $(p>0,05)$.

Kualitas hidup pasien MG di RSUP Dr. M. Djamil Padang kelas I 100\% baik, kelas II 87,5\% baik, dan kelas III 85,7\% baik. Kualitas hidup pasien MG di RSUP Dr. M. Djamil Padang yang menderita MG <45 bulan $89,5 \%$ baik, dan $>45$ bulan $89,5 \%$ baik. Tidak ada hubungan antara pasien miastenia gravis yang menderita $<45$ bulan dengan $>45$ bulan terhadap kualitas hidup $(p>0,05)$.

\section{Perbandingan Skor Akhir Kualitas Hidup Berdasarkan Karakteristik Responden}

Gambar 2 memperlihatkan bahwa skor dimensi fisik lebih rendah dibandingkan dengan skor dimensi psikologis untuk semua karakteristik responden. Ratarata skor akhir kelompok usia 50-79 tahun lebih tinggi dibandingkan kelompok usia 20-49 tahun. Rerata skor akhir jenis kelamin laki-laki lebih tinggi dibanding perempuan. Terjadi penurunan skor akhir seiring dengan meningkatnya kelas MGFA dan lama menderita. 


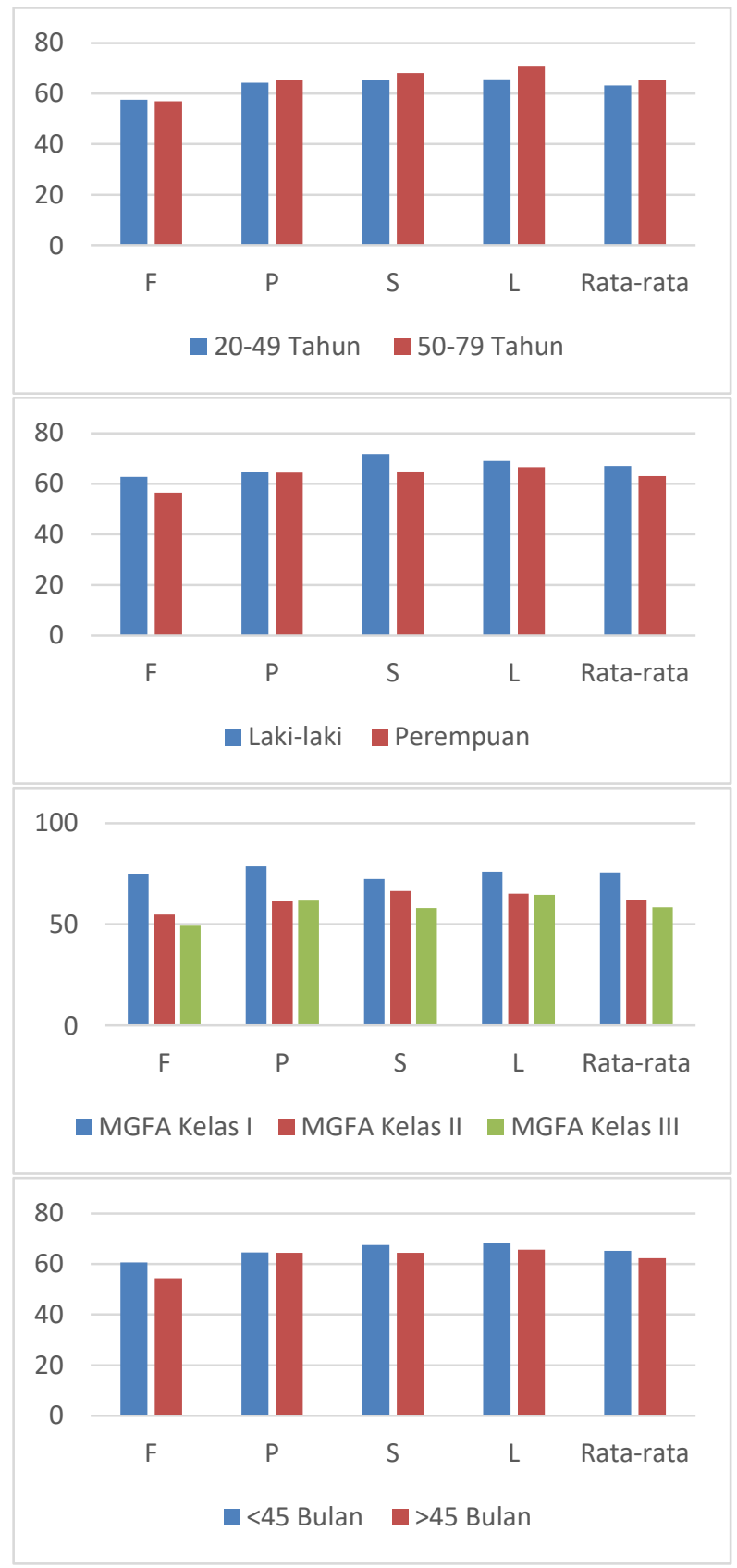

Gambar 2. Diagram perbandingan skor akhir kualitas hidup (ordinat) berdasarkan karakteristik (aksis) responden; dari gambar atas kebawah, kelompok usia, jenis kelamin, kelas MGFA, lama menderita.

${ }^{*} F=$ Dimensi Fisik, $P=$ Dimensi Psikologis, $S=$ Dimensi Hubungan Sosial, L= Dimensi Lingkungan

\section{PEMBAHASAN}

Hasil penelitian di Bagian Saraf RSUP Dr. M. Djamil Padang penderita MG mayoritas responden adalah berjenis kelamin perempuan yakni sebanyak 32 orang (84,2\%). Berdasarkan tingkat usia kebanyakan responden berusia 20-49 tahun yakni sebanyak 29 orang (76,3\%).Berdasarkan kelas MG oleh MGFA, kebanyakan responden ditemukan pada kelas II yakni sebanyak 24 orang (63,2\%). Berdasarkan lama menderita didapatkan median 45 bulan atau 3,75 tahun dengan rata-rata lama menderita yakni 56,87 bulan atau 4,74 tahun.

Penelitian ini serupa dengan penelitian yang dilakukan oleh Ghea dan Magdalena, yang mana mayoritas penderita miastenia gravis adalah perempuan dengan $86,67 \%$. $^{13}$ Sebuah penelitian menyebutkan bahwa miastenia gravis dapat terjadi pada semua kelompok usia baik laki-laki maupun perempuan dengan perbandingan antara perempuan dan laki-laki adalah 3:2. ${ }^{14}$ Penelitian ini juga sejalan dengan penelitian yang dilakukan oleh Tri et al, yang mana sebagian besar responden berusia di bawah 50 tahun atau early onset myasthenia gravis (EOMG) dengan rentang usia menderita adalah 35-44 tahun. ${ }^{3}$ Penelitian ini juga sejalan dengan penelitian oleh Ghea dan Magdalena, yang menemukan mayoritas pasien MG berusia direntang 21-40 tahun dengan 73,33\%. Tingginya kejadian EOMG salah satunya berhubungan dengan adanya timoma yang berkembang pada usia dibawah 40 tahun. ${ }^{13}$ Mayoritas responden MG berada pada MGFA kelas II dengan 53,33\%. ${ }^{13}$

Berdasarkan analisis diketahui kualitas hidup baik (skor akhir 51-100) pada perempuan secara persentase lebih tinggi dibanding laki-laki dengan perbandingan persentase yakni 90,3\%:83,3\%. Rerata skor dalam hal ini laki-laki justru memiliki rerata skor akhir lebih tinggi dibanding perempuan, dengan perbandingan skor akhir laki-laki dibanding perempuan yakni 67,0:63,1. Hal ini terjadi disebabkan karena tidak sebandingnya jumlah laki-laki dan perempuan pada responden. Rerata skor akhir laki-laki yang lebih tinggi dibanding rerata skor akhir perempuan, sejalan dengan penelitian Yongxiang et al, yang mana menyebutkan skor akhir laki-laki juga lebih tinggi dibanding skor akhir perempuan menggunakan kuesioner SF-36. ${ }^{7}$

Berdasarkan analisis diketahui adanya kecenderungan atau tren penurunan kualitas hidup seiring dengan meningkatnya kelas miastenia gravis. Hal ini sejalan dengan penelitian Yongxiang et al, yang juga menunjukkan adanya kecenderungan atau tren penurunan kualitas hidup seiring dengan meningkatnya derajat keparahan miastenia gravis. ${ }^{7}$ 
Berdasarkan analisis diketahui bahwa kualitas hidup pada kelompok usia 20-49 tahun 86,2\% baik, begitupun halnya dengan rerata skor akhir. Seiring meningkatnya usia maka kemampuan jaringan untuk memperbaiki diri akan berkurang sehingga mempengaruhi struktur dan fungsi jaringan tersebut. Perubahan yang terjadi akibat proses penuaan diantaranya penurunan fungsi panca indra, munculnya penyakit-penyakit degeneratif, serta perubahan pada kognitif. Penelitian oleh Ghea dan Magdalena memiliki hasil rendah dalam verbal comprehension, kemampuan visual motorik, daya ingat, atensi dan proses berpikir cepat. ${ }^{13}$

Aalisis data diketahui bahwa rerata skor akhir kualitas hidup pasien MG mengalami penurunan seiring dengan lamanya menderita, akan tetapi penurunan skor tersebut tidak bermakna secara statistik. Penelitian ini sejalan dengan penelitian oleh Rehabilitation Centre for Neuromuscular Diseases yang juga menemukan penurunan rerata skor akhir kualitas hidup seiring dengan lama menderita. ${ }^{9}$

Berdasarkan analisis data juga diketahui bahwa rerata domain fisik lebih tinggi dibanding domain psikologis. Hal ini sejalan dengan penelitian oleh Boldingh et al yang juga menemukan rerata skor fisik (PCS) lebih rendah dibanding skor psikologis (MCS). ${ }^{16}$

\section{SIMPULAN}

Terdapat kecenderungan penurunan skor akhir kualitas hidup seiring dengan meningkatnya kelas MGFA.

Terdapat kecenderungan penurunan skor akhir kualitas hidup seiring dengan lama menderita.

\section{DAFTAR PUSTAKA}

1. Anthony AA, James AR. Neuromuscular disorders. New York: The McGraw Hill Companies, Inc; 2008. hal.457-465.

2. US Department of Health \& Human Services. Myasthenia gravis. [serial online] 2017 (diunduh Oktober 2017. Tersedia dari: http://www. womenshealth.gov/a-z-topics/myasthenia-gravis.

3. Tri A, I Made K, Debie D. Gambaran karakteristik pasien miastenia gravis di pulau Jawa. Jurnal Kesehatan Bhakti Husada.2016; 3(1):33-7.
4. Myasthenia Gravis Foundation of America. The MGFA clinical classification [serial online] 2017 (diunduh Oktober 2017). Tersedia dari: http://www.myasthenia.org/LinkClick.aspx?fileticke $\mathrm{t}=$ slitErMYbkA\%3d\&tabid $=125$

5. James FH, Brian PB, Madeleine B, Susan GB, Timothy $\mathrm{H}$, Kimberly MJ, et al. Myasthenia gravis a manual for the health care provider. St. Paul: Myasthenia Gravis Foundation of America; 2008. $\mathrm{hlm} .8-83$.

6. Köhler W. Psychosocial aspects in patients with myasthenia gravis. Journal Neurol. 2008; 255(2):309-10.

7. Yongxiang $Y$, Min Z, Jun G, Shan M, Lingling $F$, Xianni W, et al. Quality of life in 188 patients with myasthenia gravis in China. International Journal of Neuroscience. 2016;126(5):455-62.

8. Rakesh K, Madhu N, Sanjib S, Arun BT, Shivaji R. MG-QoL-15 scores in treated myasthenia gravis: experience from a university hospital in India. Neurology India. 2016; 64(3):405-10.

9. Rehabilitation Centre for Neuromuscular Diseases. Characteristics of long-time patients with myasthenia gravis in a Danish population. [serial online] 2017 (diunduh Oktober 2017). Tersedia dari:http://rcfm.dk/wpcontent/uploads/2017/05/Pati ents-with-Myasthenia-Gravis-1016-x-762-mm..pdf

10. WHO. Constitution of WHO: principles. [serial online] 2017 (diunduh Oktober 2017). Tersedia dari: http://www.who.int/about/mission/en/

11. WHO. WHOQOL: measuring quality of life [serial online] 2017 (diunduh Oktober 2017). Tersedia dari: http://www.who.int/healthinfo/survey/whogolqualityoflife/en/

12. Oktavianus CS, Novia IS, Rina KK, Adi H. Validitas dan reliabilitas World Health Organization Quality of Life-BREF untuk mengukur kualitas hidup usia lanjut. Universa Medicina. 2007;26(1):27-37.

13. Ghea AA, Magdalena SH. Gambaran aspek kognitif dan kepribadian pasien myasthenia gravis. Jurnal Psikogenesis. 2013; 2(1):19-61.

14. Muscular Dystrophy association of New Zealand Inc. Myasthenia gravis [serial online] 2017 (diunduh Oktober 2017). Tersedia dari: 
http://mda.org.nz/Neuromuscular-Conditions/

Conditions-Overview/Diseases-of-the-

Neuromuscular-Junction/Myasthenia-Gravis.

15. Boedhi D. Buku ajar geriatri. Jakarta: Balai Penerbit FKUI; 2009.hlm.1-34.
16. Boldingh MI, Dekker L, Maniao AH, Brunborg C, Lipka AF, Niks EH, et al. An up-date on healthrelated quality of life in myasthenia gravis-results from population based cohorts. Health and quality of life outcomes. 2015; 3(5):1-14. 